\title{
Wpływ wybranych czynników socjomedycznych na jakość życia i funkcjonowanie psychoseksualne kobiet po leczeniu operacyjnym raka gruczotu piersiowego*
}

\author{
The effect of selected socio-medical factors on quality of life and psychosexual functioning \\ in women after surgical treatment of breast cancer
}

\author{
Sebastian Artur Zdończyk \\ Wydział Nauk Społecznych Akademii Pomorskiej \\ ul. Bohaterów Westerplatte 64, 76-200 Stupsk \\ Kierownik: prof. zw. dr hab. Iryna Surina
}

\begin{abstract}
SUMMARY
Introduction: According to the National Cancer Registry, 16534 new cases of breast cancer were confirmed in 2011 in Poland. Surgical treatment poses not only a serious oncological problem but also a cosmetic and psychological one. Women fear they will lose their femininity and sexual attractiveness after the surgery. They feel defective (half woman complex) and they experience such feelings as shame, anger and depression. Sexuality is a sphere of life that is particularly susceptible to all kinds of perturbation of physical and mental states.

The main cognitive objective of the presented research is the analysis of life quality level and mental and sexual functioning of women who underwent breast cancer surgical treatment. Material and methods: The research was carried out from October 2013 to February 2014 among 250 adult women who underwent breast cancer surgery. The questionnaire includes questions regarding sociomedical and sociosexology questions, and five standardised research tools: Life Quality Questionnaire SF-36 v. 2, licence No. QM020862, Mell-Krat Questionnaire prepared by Z. Lew-Starowicz, Female Sexual Function Index Questionnaire, A List of Health Behaviours by Z. Juczyński, Courtauld Emotional Control Scale (CECS) adapted
\end{abstract}

by Z. Juczyński. The research received a positive opinion from the Bioethical Commission of The Pomeranian Medical University in Szczecin.

Results: On the basis of the conducted research and statistical analyses it was found that the extensiveness of the surgical procedure, the effectiveness of oncological treatment, age, the number of children, education, material conditions, and the occupational status of the subject women have an impact on life quality and psychosexual functioning.

Conclusions: Women who underwent mastectomy with reconstruction of the mammary gland gained higher results in comparison to women who underwent mastectomy without reconstruction as regards physical and mental functioning within life quality. The respondents who had their oncological treatment completed were featured with a lower intensity of sexual dysfunctions than women who had their treatment in progress. The participants of the research with higher educational level, high material status and stable job condition had higher indicators of health behaviours intensity than women with lower material status and lower educational level.

Key words: quality of life, female sexual dysfunction, breast cancer, sexuality of women, psychooncology.

\section{STRESZCZENIE}

Wstęp: Według Krajowego Rejestru Nowotworów w 2011 r. stwierdzono w Polsce 16534 nowe zachorowania na raka piersi oraz zarejestrowano 5437 zgonów. Leczenie chirurgiczne stanowi nie tylko poważny problem onkologiczny, lecz również kosmetyczny i psychologiczny. Kobiety odczuwają lęk przed utratą kobiecości i atrakcyjności seksualnej po operacji. Czują się niepełnowartościowe („,kompleks połowy kobiety”) oraz towarzyszą im takie uczucia jak: wstyd, gniew i depresja. Seksualność jest sferą życia szczególnie podatną na wszelkie zakłócenia stanów fizycznego i psychicznego.

Podstawowym celem poznawczym prezentowanych badań była ocena poziomu jakości życia i funkcjonowania psychoseksualnego kobiet po leczeniu operacyjnym raka gruczołu piersiowego.
Materiał i metody: Badania przeprowadzono w grupie 250 dorosłych kobiet po leczeniu chirurgicznym raka piersi. Ankieta zawierała pytania dotyczące czynników socjomedycznych i socjoseksuologicznych oraz pięć standaryzowanych narzędzi badawczych: Kwestionariusz oceny jakości życia SF-36 v.2, Kwestionariusz Mell-Krat opracowany przez Z. Lwa-Starowicza, Kwestionariusz FSFI - Ocena Funkcjonowania Seksualnego Kobiet, Inwentarz Zachowań Zdrowotnych (IZZ) autorstwa Z. Juczyńskiego, Skalę Kontroli Emocji (CECS) - w adaptacji Z. Juczyńskiego. Badania uzyskały pozytywną opinię Komisji Bioetycznej Pomorskiego Uniwersytetu Medycznego w Szczecinie.

Wyniki: Na podstawie przeprowadzonych badań i analiz statystycznych wykazano, że wpływ na jakość życia i funkcjonowanie psychoseksualne mają: rozległość zabiegu operacyjnego,

* Zwięzła wersja rozprawy doktorskiej przyjętej przez Radę Wydziału Nauk o Zdrowiu Pomorskiego Uniwersytetu Medycznego w Szczecinie. Promotor: dr hab. n. med., prof. PUM Agnieszka Brodowska. Oryginalny maszynopis obejmuje 150 stron, 38 tabel, 74 ryciny, 355 pozycji wykorzystanego piśmiennictwa. 
skuteczność leczenia onkologicznego, wiek, liczba posiadanych dzieci, wykształcenie, sytuacja materialna oraz sytuacja zawodowa badanych kobiet.

Wnioski: Kobiety, u których wykonano mastektomię z rekonstrukcją gruczołu piersiowego, uzyskały wyższe wyniki od kobiet po mastektomii bez wykonanej rekonstrukcji w obszarze fizycznego i psychicznego funkcjonowania w zakresie jakości życia. Respondentki, u których zostało zakończone leczenie onkologiczne, charakteryzowały się niższym nasileniem dysfunkcji seksualnych niż kobiety w trakcie leczenia. Uczestniczki badań z wyższym wykształceniem, wysokim statusem materialnym i stabilną sytuacją zawodową odznaczały się wyższym wskaźnikiem nasilenia zachowań zdrowotnych niż kobiety z niskim statusem materialnym i wykształceniem.

Słowa kluczowe: jakość życia, zaburzenia seksualne, rak piersi, seksualność kobiet, psychoonkologia.

\section{WSTĘP}

Rak piersi jest najczęściej występującym nowotworem złośliwym u kobiet na całym świecie. We wszystkich krajach europejskich w 2012 r. nowotwory piersi stanowiły pierwszą, najliczniejszą grupę pośród zachorowań na nowotwory złośliwe u kobiet [1, 2]. W 2011 r. według Krajowego Rejestru Nowotworów w Polsce stwierdzono 16534 nowych zachorowań na raka piersi (standaryzowany współczynnik zachorowalności to 51,8/100 000 - stan na dzień 30.06.2011 r.). Obserwacja częstości zachorowań w poszczególnych grupach wiekowych wykazała, że drastyczny wzrost zachorowań występuje w przedziale wiekowym 50-69 lat [3, 4]. W Polsce rak piersi jest przyczyną największej liczby zgonów spowodowanych przez nowotwory złośliwe wśród kobiet [5, 6]. W 2011 r. zarejestrowano 5437 zgonów (standaryzowany współczynnik umieralności 14,2/100 000 - stan na 30.06.2011 r.).

Leczenie chirurgiczne jest najstarszą, główną metodą leczenia chorób nowotworowych. Stanowi fundamentalną i niezastąpioną część multidyscyplinarnego leczenia raka piersi [7, 8]. W chirurgii raka piersi stosowane zabiegi można podzielić na 4 główne typy: zabiegi diagnostyczne, zabiegi lecznicze, zabiegi paliatywne i zabiegi rekonstrukcyjne. Decyzja dotycząca wyboru metody leczenia chirurgicznego jest procesem złożonym. Ważnym etapem podczas podejmowania decyzji o metodzie leczenia jest poinformowanie pacjentki i uzyskanie jej zgody na zaproponowany sposób leczenia chirurgicznego $[8,9,10]$. Operacja odtwórcza piersi (rekonstrukcja) wpływa na poprawę stanu psychofizycznego kobiety i na jakość życia [11].

Zgodnie z definicją Światowej Organizacji Zdrowia (World Health Organization - WHO), jakość życia to „postrzeganie przez jednostki ich pozycji w życiu, w kontekście kulturowym i systemu wartości, w którym żyją, oraz jej związku z indywidualnymi celami w odniesieniu do zadań, oczekiwań, zainteresowań i standardów wyznaczonych uwarunkowaniami środowiskowymi". Wobec powyższego, jakość życia to całościowy system oceniania przez jednostkę własnego zdrowia fizycznego, stanu psychicznego, samodzielności i poczucia niezależności od otoczenia, a także relacji z otoczeniem oraz własnych przekonań i wierzeń $[12,13,14,15,16]$. Jednym z podstawowych determinantów jakości życia jest zdrowie. Kategorię jakości życia uwarunkowanej stanem zdrowia (health related quality of life - HRQoL) wprowadził do medycyny Schipper wraz ze swoimi współpracownikami. Zdefiniował on HRQoL jako „funkcjonalny efekt choroby i jej leczenia odbierany (przeżywany) przez pacjenta $[17,18]$. Wynika z tego, że HRQoL można rozpatrywać i analizować jako koncepcję wielopoziomową, reprezentującą wynik wspólnego działania sfer wpływających na zdrowie, takich jak funkcjonowanie fizyczne, psychiczne, społeczne, ogólne samopoczucie i zadowolenie z życia oraz postrzeganie zdrowia [19]. Poza przy toczonymi głównymi obszarami HRQoL uwzględnia także wymiary funkcjonowania ludzi chorych, jak: seksualność, uczestnictwo w kulturze i duchowość. Wiele chorób można skutecznie leczyć. Istotne stało się jednak nie tylko przedłużanie ludzkiego życia, ale również ułatwienie pacjentom uczestnictwa w aktywnym życiu na poziomie jak najbardziej zbliżonym do ludzi zdrowych.

Choroby nowotworowe są różnorodną grupą schorzeń pod względem obrazu klinicznego i możliwości postępowania terapeutycznego [20]. Metody terapeutyczne stosowane w onkologii są agresywne i budzą powszechny lęk z powodu sposobu ich wykonania, objawów ubocznych i przewidywanych skutków [21]. Brak możliwości prognozowania, w jaki sposób i w jakim kierunku potoczy się choroba nowotworowa i jej rozwój, powoduje powstanie niepewności, która wywołuje w życiu osoby chorej, a często i jej otoczenia, poważny, nierzadko długotrwały kryzys psychologiczny. Do najczęściej towarzyszących i najbardziej charakterystycznych w przebiegu choroby nowotworowej zalicza się takie emocje, jak: lęk, gniew, obniżony nastrój, agresja, rozdrażnienie [22, 23, 24]. Wraz z podjęciem leczenia onkologicznego pacjenci odczuwają zmienne emocje [25]. Z jednej strony towarzyszy im nadzieja na wyzdrowienie, a z drugiej - pojawia się lęk przed negatywnymi skutkami leczenia i niepewnością rokowania na wyzdrowienie. Uraz i lęk psychiczny związany z amputacją całkowitą bądź częściową piersi jest ogromny. Kobiety odczuwają lęk przed utratą kobiecości i atrakcyjności seksualnej po operacji. Czują się niepełnowartościowe („kompleks połowy kobiety”). Wiele pacjentek odczuwa strach przed rozbiciem rodziny lub odejściem partnera. Sferą życia szczególnie podatną na wszelkiego rodzaju zakłócenia stanów fizycznego i psychicznego jest funkcjonowanie psychoseksualne i seksualność.

Seksualność - niezbywalny atrybut człowieka - sprawia, że na każdym etapie życia można podejmować nowe, związane z nią wyzwania, cieszyć się jej nowymi aspektami i przyjmować wynikające z niej ograniczenia. Jest wrodzonym atrybutem i wrodzoną funkcją ludzkiego organizmu, podlegającą złożonym zewnętrznym i wewnętrznym uwarunkowaniom, które wymagają szerokiego spojrzenia i interdyscyplinarnego wysiłku [26, 27]. Doświadczana i wyrażana w myślach, fantazjach, przeżyciach, przekonaniach, wartościach, zachowaniach, 
rolach i związkach seksualność powstaje na skutek interakcji czynników biologicznych, psychologicznych, społecznych, ekonomicznych, politycznych, kulturowych, etycznych, prawnych, historycznych, religijnych i duchowych $[28,29]$.

Zaburzenia seksualne kobiet można opisać na kontinuum: od dyssatysfakcji (fizjologiczne zmiany wraz z emocjonalną frustracją), przez dysfunkcje (patologiczne reakcje zarówno fizyczne, jak i afektywne), po zaburzenia seksualne (fizyczna patologia i dysfunkcyjność narządów seksualnych oraz zaburzenia psychiczne) [30, 31]. Zaburzenia seksualne kobiet (female sexual dysfunction) zostały zdefiniowane w 4 kategoriach: zaburzenia pożądania, zaburzenia podniecenia, zaburzenia orgazmu, zaburzenia związane z bólem [32,33]. Natura problemów seksualnych jest często złożona i może zmieniać się w ciągu różnych okresów życia. Do czynników ryzyka powyższych dysfunkcji zalicza się: ogólny stan zdrowia, cukrzycę, choroby przewlekłe, w tym choroby nowotworowe, choroby układu sercowo-naczyniowego i moczowo-płciowego, zaburzenia hormonalne i psychiczne oraz cały szereg czynników psychologicznych, kulturowych i społeczno-demograficznych [34, 35, 36, 37].

Wśród metod leczenia dysfunkcji seksualnych stosuje się metody biologiczne, fizykalne i metody psychologiczne [38]. Wybór metody leczenia zaburzeń seksualnych u kobiet powinien uwzględniać etiopatogenezę i stopień nasilenia dysfunkcji, a ryzyko wystąpienia działań niepożądanych wynikających ze stosowanej terapii nie powinno przewyższać jej korzyści [39].

Choroba nowotworowa i jej leczenie wpływają na zdrowie seksualne i reprodukcyjne kobiet, utrudniają funkcjonowanie psychofizyczne, a także relacje społeczne [40, 41]. Amputacja piersi narusza obraz każdej kobiety zarówno w jej ocenie, jak i w odbiorze społecznym. W funkcjonowaniu seksualnym znaczącą rolę odgrywa akceptacja własnej cielesności. Konsekwencją braku akceptacji fizyczności jest wstyd i lęk blokujący ochotę na seks $[42,43]$. Piersi i sutki są dla wielu kobiet źródłem seksualnej przyjemności i mogą stanowić dodatkowy bodziec powodujący zwiększenie podniecenia [44].

W procesie rehabilitacji psychofizycznej kobiet leczonych z powodu nowotworów złośliwych piersi możliwość wykonania operacji odtwórczej zajmuje bardzo wyjątkowe miejsce. Rekonstrukcja znacząco wpływa na poprawę jakości życia i emocjonalnego funkcjonowania (stanu) leczonych kobiet, co w znaczny sposób poprawia funkcjonowanie w obszarze psychoseksualnym.

\section{MATERIAŁ I METODY}

Przeprowadzone badanie było częściowe (badano wybrane jednostki z danej zbiorowości). W badaniach zastosowano dobór celowy, nieprobabilistyczny. Kryteriami doboru osób do badań były: przestrzeń i środowisko społeczne - kluby kobiet leczonych z powodu choroby nowotworowej piersi („Amazonki”). Obserwację statystyczną (pomiar sondażowy) [45] opinii i postaw przeprowadzono przy użyciu sondażu diagnostycznego. Zastosowaną techniką badawczą była ankieta, a narzędziem badawczym składający się z 6 części kwestionariusz ankiety. Kwestionariusz zawierał pytania dotyczące czynników socjomedycznych i socjoseksuologicznych oraz 5 standaryzowanych narzędzi badawczych: Kwestionariusz oceny jakości życia SF-36 v.2, Kwestionariusz Mell-Krat opracowany przez Z. Lwa-Starowicza, Kwestionariusz FSFI Ocena Funkcjonowania Seksualnego Kobiet, Inwentarz Zachowań Zdrowotnych (IZZ) autorstwa Z. Juczyńskiego, Skala Kontroli Emocji (CECS) - w adaptacji Z. Juczyńskiego. Badania przeprowadzono w okresie od października 2013 r. do lutego 2014 r. w grupie dorosłych kobiet po leczeniu chirurgicznym raka piersi. Do ostatecznej analizy statystycznej zostało wybranych 250 poprawnie wypełnionych kwestionariuszy. Badania uzyskały pozytywną opinię Komisji Bioetycznej Pomorskiego Uniwersytetu Medycznego w Szczecinie. Obliczenia własne wykonano przy zastosowaniu funkcji arkusza kalkulacyjnego Microsoft Office Excel 97-2003 for Windows oraz pakietu Statistica w wersji 10. Za poziom istotności statystycznej celem poprawnego interpretowania otrzymanych wyników przyjęto wartość $\mathrm{p} \leq 0,05$.

\section{WYNIKI}

Średni wiek badanych to $62,6 \pm 8,7$ lat. Blisko $70 \%$ stanowiły kobiety zamężne. Pozostałe $30 \%$ to osoby stanu wolnego. Ponad połowa ankietowanych $(55,2 \%)$ legitymowała się wykształceniem średnim i policealnym (pomaturalnym). Dyplom ukończenia uczelni wyższej posiadała co trzecia badana $(30,4 \%)$, a tylko $2 \%$ edukację zakończyło na poziomie szkoły podstawowej. Pozostałe badane zadeklarowały wykształcenie zawodowe. Ponad 40\% respondentek oceniło swoją sytuację materialną jako przeciętną. Blisko 40\% umiejscowiło swój status ekonomiczny na poziomie dobrym. Kobiety będące w trudnej i bardzo trudnej sytuacji materialnej stanowiły łącznie 10,8\% badanych. Niespełna 8\% określiło swoją sytuację materialną jako bardzo dobrą. Wśród badanych kobiet przeważały te, które urodziły dwoje dzieci (51,2\%) oraz kobiety, które urodziły jedno dziecko (23,6\%). Kobiet bezdzietnych było 8\%. Trójkę i więcej dzieci urodziło ponad $17 \%$. U ponad połowy badanych kobiet czas, jaki upłynął od momentu operacji do dnia badania kwestionariuszowego, wynosił więcej niż 5 lat. Blisko 6\% respondentek interwencji chirurgicznej poddanych zostało w przeciągu ostatnich 12 miesięcy. Z danych wynika, że w ciągu 12-24 miesięcy zoperowanych zostało 12,4\% ankietowanych, a w przedziale 2-5 lat ponad 20\%. Najczęściej (59,2\%) interwencja chirurgiczna polegała na mastektomii jednostronnej bez wykonania rekonstrukcji piersi. Operacji oszczędzającej poddanych zostało blisko $18 \%$ badanych. U 16\% operowanych wykonano rekonstrukcję gruczołu piersiowego. W wyniku leczenia operacyjnego u ponad 7\% przeprowadzono amputację obu piersi. Liczniejszą grupę $(46,4 \%)$ stanowiły badane, u których zmiany nowotworowe dotyczyły piersi lewej, natomiast o $2 \%$ mniej kobiet miało zmiany w piersi prawej. Najmniejszą grupę stanowiły respondentki, u których choroba dotyczyła obu piersi. Dla 76,8\% badanych kobiet leczenie choroby 
TABELA 1. Profil Skala SF-36 - statystyki opisowe

\begin{tabular}{|c|c|c|c|c|c|c|c|c|c|c|}
\hline & Średnia & Mediana & Moda & $\begin{array}{l}\text { Liczność } \\
\text { mody }\end{array}$ & Minimum & Maksimum & $\begin{array}{l}\text { Dolny } \\
\text { kwartyl }\end{array}$ & $\begin{array}{l}\text { Górny } \\
\text { kwartyl }\end{array}$ & Rozstęp & SD \\
\hline PF Funkcjonowanie fizyczne & 66,9 & 70 & 75 & 27 & 0 & 100 & 55 & 80 & 100 & 21,4 \\
\hline RP Ograniczenia w aktywności fizycznej & 56,6 & 56,3 & 50 & 45 & 0 & 100 & 44 & 69 & 100 & 23,7 \\
\hline BP Dolegliwości bólowe & 37,9 & 42,5 & 0 & 46 & 0 & 100 & 20 & 55 & 100 & 26,3 \\
\hline GH Ogólne poczucie zdrowia & 58,5 & 60 & 50 & 40 & 30 & 90 & 50 & 65 & 60 & 10,8 \\
\hline VT Żywotność & 46,7 & 50 & 50 & 60 & 6 & 100 & 38 & 50 & 94 & 10,9 \\
\hline SF Funkcjonowanie społeczne & 50,3 & 50 & 50 & 108 & 13 & 100 & 38 & 50 & 88 & 12,9 \\
\hline $\begin{array}{l}\text { RE Ograniczenia w funkcjonowaniu } \\
\text { emocjonalnym }\end{array}$ & 64,2 & 66,7 & 100 & 45 & 0 & 100 & 50 & 83 & 100 & 25,3 \\
\hline MH Zdrowie psychiczne & 55 & 55 & 55 & 57 & 30 & 100 & 50 & 60 & 70 & 9,6 \\
\hline Ocena strefy fizycznej & 55 & 55,6 & 61 & 11 & 25 & 88,8 & 50,3 & 60,6 & 63,8 & 9 \\
\hline Ocena strefy psychicznej & 54 & 53,9 & wielokr. & 6 & 18 & 87,5 & 49,4 & 59,8 & 69,9 & 9,1 \\
\hline
\end{tabular}

Źródło: opracowanie własne

nowotworowej piersi zostało zakończone. Ponad 20\% nadal pozostawało $\mathrm{w}$ procesie leczenia (chemioterapii, radioterapii, hormonoterapii).

\section{Ocena jakości życia}

W tabeli 1 przedstawiono wyniki miar tendencji centralnych dla jakości życia w poszczególnych komponentach oraz ocenę strefy psychicznej i fizycznej. Ocena strefy psychicznej i fizycznej osiągnęła wartość powyżej 50, co wskazuje na dobre (w normie) poczucie zdrowia. W zakresie poszczególnych domen jakości życia, poniżej normy wartość osiągnęły VT - żywotność $(46,7)$ oraz BP - dolegliwości bólowe $(37,9)$. Najwyższą wartość oznaczającą najlepsze zdrowie osiągnęły domeny: PF - funkcjonowanie fizyczne $(66,9)$ oraz RE - ograniczenia w funkcjonowaniu emocjonalnym $(64,2)$. Ogólne poczucie zdrowia - GH osiągnęło wartość 60, co jest jednoznaczne z usytuowaniem w obszarze dobrego zdrowia. Jakość życia w obszarze PF funkcjonowania fizycznego okazała się zmienną bardziej zróżnicowaną, gdyż SD (odchylenie standardowe) wynosi 21,4, a w przypadku SF funkcjonowania społecznego SD wynosi 12,9.

W tabeli 2 przedstawiono wpływ rodzaju przeprowadzonej operacji na ocenę sfery psychicznej respondentek. Wartość p = ,005472, w związku z tym istnieje istotna statystycznie zależność. Przeprowadzona analiza pokazuje, że kobiety

TABELA 2. Rodzaj operacji a sfera psychiczna SF-36

\begin{tabular}{|c|c|c|c|}
\hline Rodzaj operacji & $\begin{array}{c}\text { Ocena strefy } \\
\text { psychicznej } \\
\text { wyniki poniżej } \\
\text { normy }\end{array}$ & $\begin{array}{c}\text { Ocena strefy } \\
\text { psychicznej } \\
\text { wyniki powyżej } \\
\text { normy }\end{array}$ & Statystyka \\
\hline $\begin{array}{l}\text { Operacja } \\
\text { oszczędzająca }\end{array}$ & 22,50 & 77,50 & \multirow{4}{*}{$\begin{array}{c}x^{2} \text { Pearsona: } \\
14,6569, \\
d f=4, \\
p=, 005472\end{array}$} \\
\hline $\begin{array}{l}\text { Mastektomia } \\
\text { jednostronna bez } \\
\text { rekonstrukcji piersi }\end{array}$ & 70,23 & 29,77 & \\
\hline $\begin{array}{l}\text { Mastektomia } \\
\text { jednostronna } \\
\text { z rekonstrukcją } \\
\text { piersi }\end{array}$ & 6,45 & 93,55 & \\
\hline $\begin{array}{l}\text { Mastektomia } \\
\text { obustronna }\end{array}$ & 81,25 & 18,75 & \\
\hline
\end{tabular}

Źródło: opracowanie własne po mastektomii jednostronnej z rekonstrukcją piersi uzyskały najwyższy wynik w ocenie strefy psychicznej w grupie powyżej normy.

Wartość p = ,022984, więc istnieje istotna statystycznie zależność pomiędzy stanem związanym z aktualnym leczeniem a oceną sfery fizycznej. Najwyższe wyniki w ocenie strefy fizycznej w grupie powyżej normy uzyskały kobiety, u których leczenie zostało zakończone. Natomiast badane, które są w trakcie leczenia radioterapią, uzyskały najwyższe wyniki w ocenie sfery fizycznej w grupie poniżej normy (tab. 3).

TABELA 3. Stan aktualnego leczenie a sfera fizyczna SF-36

\begin{tabular}{|c|c|c|c|}
\hline Aktualne leczenie & $\begin{array}{l}\text { Ocena strefy } \\
\text { fizycznej } \\
\text { wyniki poniżej } \\
\text { normy }\end{array}$ & $\begin{array}{l}\text { Ocena strefy } \\
\text { fizycznej } \\
\text { wyniki } \\
\text { powyżej } \\
\text { normy }\end{array}$ & Statystyka \\
\hline $\begin{array}{l}\text { Nie poddałam się } \\
\text { leczeniu }\end{array}$ & 50,00 & 50,00 & \multirow{4}{*}{$\begin{array}{c}x^{2} \text { Pearsona: } \\
\text { 14,6709, } \\
d f=6, \\
p=, 022984\end{array}$} \\
\hline $\begin{array}{l}\text { Leczenie zostało } \\
\text { zakończone }\end{array}$ & 19,41 & 80,59 & \\
\hline $\begin{array}{l}\text { Jestem w trakcie } \\
\text { chemioterapii }\end{array}$ & 50,00 & 50,00 & \\
\hline $\begin{array}{l}\text { Jestem w trakcie } \\
\text { radioterapii }\end{array}$ & 66,67 & 33,33 & \\
\hline Hormonoterapia & 33,33 & 66,67 & \\
\hline
\end{tabular}

Źródło: opracowanie własne

\section{Ocena funkcji seksualnych i seksualności}

Zdecydowana większość badanych zadeklarowała, że jest orientacji heteroseksualnej. Jako osoby homoseksualne określiło siebie 5\% respondentek, a 1\% badanych wskazało na orientację biseksualną. Jednym z obszarów ludzkiej seksualności są zachowania masturbacyjne. Blisko 25\% nie zaznaczyła żadnej odpowiedzi. Praktykowanie zachowań autoerotycznych w przeszłości zadeklarowało blisko 40\%, z tego tylko niecałe $8 \%$ wskazało odpowiedź, że masturbują się teraz i w przeszłości; 28,8\% badanych odpowiedziało, że nigdy nie praktykowała zachowań autoerotycznych. Na pytanie o aktywność seksualną podobna liczba osób (odpowiednio 24,8\% i $27,2 \%$ ) wskazała odpowiedź, że nie prowadzi aktywności 
seksualnej bądź ostatnia aktywność seksualna miała miejsce w ciągu ostatnich 7 dni. Blisko co czwarta badana $(23,6 \%)$ ostatnią aktywność seksualną datowała na ponad 12 miesięcy temu. Około $25 \%$ wskazało na ostatnią aktywność seksualną w przedziale 1-12 miesięcy. Według wyników badań aktywność seksualna jest dla nich obecnie średnio istotna. Przed chorobą aktywność seksualna była dla 44\% respondentek dość istotna. Obecnie ponad $23 \%$ mniej badanych wskazało tę wartość. Ponad 10-krotnie wzrosła odpowiedź w domenie zupełnie nieistotna. Dla ponad 18\% aktywność seksualna jest dziś zupełnie nieistotna, gdzie przed chorobą tylko niecałe $2 \%$ wskazało taką odpowiedź. Bardzo istotna aktywność seksualna jest obecnie dla niecałych $9 \%$, gdzie przed chorobą wskazanie to dotyczyło $20 \%$ badanych. W chwili obecnej zadowolenie ze swojego życia seksualnego na poziomie dobrym łącznie zadeklarowało blisko 40\% respondentek, gdzie przed chorobą zadowolenie na poziomie dobrym wskazywało blisko 69\%. Wyraźnie rysuje się prawie 30\% spadek zadowolenia z życia seksualnego na poziomie dobrym. Źle ocenia swoje zadowolenie z życia seksualnego obecnie blisko 37\%, gdzie przed chorobą odpowiedź taką wskazało $27 \%$.

Analizując wyniki badań, stwierdzono, że najwięcej, bo aż $80 \%$ badanych kobiet ma rozpoznane zaburzenie funkcji seksualnych w zakresie pożądania, a najmniej kobiet ma rozpoznane FSD w zakresie orgazmu - 53,6\%. U 70\% respondentek rozpoznane FSD związane jest z podnieceniem. Ponad połowa (54\%) ma problemy z odczuwaniem satysfakcji seksualnej i 59\% z lubrykacją. Jeżeli chodzi o poziom ogólny FSD, to u $59,2 \%$ ankietowanych kobiet stwierdzono obecność znamiennie klinicznych dysfunkcji seksualnych.

\section{Ocena funkcjonowania psychologicznego}

Mastektomia oraz uboczne skutki leczenia (zmiany skórne, utrata włosów, wagi) wpływają negatywnie na postrzeganie wyglądu własnego ciała, co istotnie przekłada się na samoocenę, poczucie wartości i tożsamość chorego. Jak pokazano na rycinie 1 , kobiety uczestniczące $\mathrm{w}$ badaniu mają największą skłonność do hamowania (tłumienia) emocji w zakresie lęku, następnie depresji i odczuwanego gniewu. Różnice pomiędzy poszczególnymi kategoriami emocji wynosiły odpowiednio 0,5-0,7 w zakresie wartości średnich. Jeżeli chodzi o odchylenie

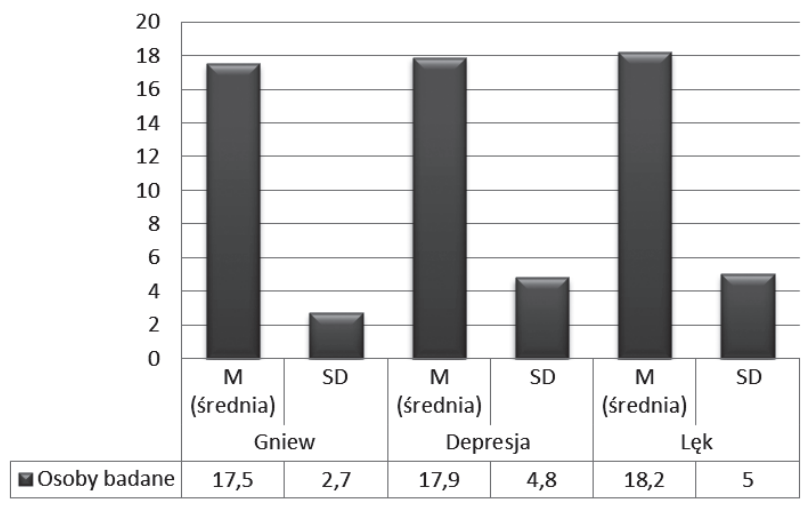

Źródło: badania własne

RYCINA 1. Poziom gniewu, lęku i depresji CECS standardowe, to w tym przypadku poziom różnic był wyższy i wynosił 2,1-2,3.

\section{DYSKUSJA}

Współczesna kultura Zachodu nadała szczególne znaczenie kultowi ciała. Piersi stanowią jeden z atrybutów uznawanych za kwintesencję seksualności i kobiecości. Rozpoznanie choroby nowotworowej powoduje uczucie niepewności, strach i niepokój. Diagnoza taka jest zawsze bardzo przykrym i w wielu przypadkach traumatycznym doświadczeniem, silnie związanym z poczuciem zagrożenia życia, niepewnością co do przyszłości, utratą kontroli nad własnym życiem, niewystarczającą ilością informacji na temat choroby i leczenia. Wzbudza szereg emocji i stanów psychofizjologicznych, które mogą znacząco wpłynąć na obniżenie jakości życia. Badania dotyczące jakości życia pozwalają lepiej zrozumieć niewykluczone następstwa fizyczne, psychologiczne, społeczne i funkcjonowanie chorych po zastosowaniu różnorodnych strategii procesu leczenia. Pomiar jakości życia jest pracochłonny, złożony i wielopłaszczyznowy. Na podstawie wyników przeprowadzonych badań stwierdzono, że na jakość życia kobiet chorych na raka piersi wpływają rozliczne czynniki $[46,47]$. Już sam proces diagnozowania, a następnie świadomość choroby nowotworowej zagrażającej życiu, jak również obawy związane z uciążliwym leczeniem i niepewną przyszłością powodują obniżenie jakości życia. W przedstawionym badaniu uzyskane statystyki opisowe (tab. 1) na wstępie porównano ze średnimi wynikami grupy porównawczej dla ogólnej populacji polskiej [48]. Na podstawie analizy kobiety biorące udział w badaniu wyżej oceniają jakość swojego życia niż grupa przyjęta do porównania. W poszczególnych obszarach różnice te wahają się na plus badanej grupy kobiet od 4,1 przy zdrowiu psychicznym do 11 przy ograniczeniach w aktywności fizycznej i funkcjonowaniu fizycznym. U kobiet z grupy uczestniczącej w badaniu większe jest natężenie i częstość silnych doznań związanych z odczuwaniem bólu. Należy zauważyć, że odchylenia standardowe tych zmiennych są niższe od odchyleń grupy porównawczej, co świadczy o mniejszych odchyleniach od wartości średniej. W wielu badaniach $[49,50]$ autorzy wykazali, że im bardziej rozległa jest interwencja chirurgiczna, tym niższa jest ocena jakości życia. Potwierdzają to również uzyskane wyniki w niniejszym badaniu. Respondentki z wykonaną rekonstrukcją piersi bądź po operacji oszczędzającej uzyskały wyższe nasilenie jakości życia niż pacjentki po obustronnej mastektomii bądź bez wykonanej rekonstrukcji gruczołu piersiowego. Goldberg i wsp. wykazali, że pacjentki po mastektomii z rekonstrukcją mają wyższy poziom samoakceptacji wpływającej na funkcjonowanie w obszarze zdrowia psychicznego niż kobiety poddane tylko mastektomii [51]. Kolejnym determinantem jakości życia w sferze funkcjonowania fizycznego był stan aktualnego leczenia. Badane kobiety, u których leczenie zostało zakończone, uzyskały najwyższe wyniki, natomiast najniższe wyniki uzyskały kobiety w trakcie radioterapii. Zapewne jest to związane z możliwością wystąpienia szeregu objawów ubocznych, m.in. 
zmęczenia, braku apetytu, zmian skórnych, suchego kaszlu oraz sztywnienia ramion. Podobne wyniki badań zaprezentowali Mor i wsp. [52]. Ocena jakości życia jest pojęciem dynamicznym i może się zmieniać w zależności od sposobu postrzegania choroby, zastosowanego leczenia, aktualnych oczekiwań i preferencji chorego, a także wraz z upływem czasu [53].

Jedną z najbardziej charakterystycznych zmian, jakie dokonały się w II połowie XX w. w świadomości ludzi, jest uznanie kluczowej roli zachowań zdrowotnych w utrzymaniu i umacnianiu własnego zdrowia. Okazuje się, że czynnikiem najbardziej mobilizującym do podejmowania zachowań zdrowotnych jest wartość, jaką przypisuje się zdrowiu [54]. Istnieje potrzeba nieustannego monitorowania zachowań związanych ze zdrowiem wśród kobiet dotkniętych chorobą nowotworową piersi. Wiele bowiem czynników ryzyka zachorowania na nowotwór gruczołu piersiowego związanych jest z prowadzonym stylem życia $[55,56]$. Zasady postępowania mającego na celu zapobieganie chorobom nowotworowym zostały ujęte w Europejskim Kodeksie Walki z Rakiem. Obejmują one wysoką aktywność ruchową i stosowanie odpowiedniej diety oraz unikanie czynników sprzyjających rozwojowi nowotworu, takich jak: palenie tytoniu i spożywanie alkoholu, a także skażenia środowiska naturalnego [57].

Zachowania prozdrowotne w przypadku seksualności wiążą się między innymi z koncepcją zdrowia seksualnego. Zdrowie seksualne (sexual health) według definicji WHO to zespół biologicznych, emocjonalnych, intelektualnych i społecznych aspektów życia seksualnego, ważnych dla pozytywnego rozwoju osobowości, komunikacji i miłości [58]. Współcześnie zdrowie seksualne kobiet rozważa się na płaszczyźnie trzech połączonych ze sobą wymiarów: seksualnej tożsamości, seksualnej sprawności oraz seksualnego związku partnerskiego [31]. W 2006 r. na łamach „The Journal of Sexual Medicine”, Hayes i wsp. stwierdzili, że wśród kobiet zgłaszających problemy seksuologiczne $64 \%$ doświadcza problemów z pożądaniem, $35 \%$ z orgazmem, $31 \%$ z podnieceniem, a $26 \%$ z bólem podczas kontaktów seksualnych [59]. Analiza zaburzeń seksualnych, które dodatkowo wywołuje choroba nowotworowa, wymaga wiedzy na temat częstości ich występowania w populacji ludzi zdrowych [60]. W przedstawionym badaniu za pomocą Indeksu Funkcji Seksualnych Kobiety (Female Sexual Function Index) FSD rozpoznano u 59,2\% respondentek. Najczęściej, bo aż 80\% cechowało się problemami w zakresie pożądania seksualnego. Następnie w kolejności najczęstszymi dysfunkcjami seksualnymi były: zaburzenia podniecenia - 70,8\%; zaburzenia lubrykacji - 59,2\%; dolegliwości bólowe (pochwica, dyspareunia) $54,8 \%$; zaburzenia satysfakcji seksualnej $54 \%$ oraz zaburzenia orgazmu -53,6\%. Uzyskane wyniki są analogiczne do badań przeprowadzonych przez Safarinejad i wsp. [61] i Laumann i wsp. [62]. Liczba uzyskanych punktów w zakresie poszczególnych domen koresponduje z badaniami Esposito i wsp. [63] oraz innych autorów badających FSD [64, 65]. Wśród czynników wpływających istotnie statystycznie na występowanie zaburzeń seksualnych kobiet znalazły się wiek, dzietność, sytuacja zawodowa, sytuacja materialna, czas jaki upłynął od momentu postawienia diagnozy, oraz aktualny stan leczenia. Zaburzenia seksualne występują częściej u chorych na nowotwory niż w populacji ogólnej. Przeprowadzone w Wielkiej Brytanii przez Macmilian Cancer Support badanie obserwacyjne wykazało, że 43\% chorych odczuło bezpośredni wpływ leczenia choroby nowotworowej na ich życie seksualne. Występowanie zaburzeń seksualnych po leczeniu raka piersi, zwłaszcza w przypadku występującej po leczeniu onkologicznym menopauzie, może wynosić nawet 70\% [66]. W przypadku kobiet z rakiem piersi najważniejsze znaczenie ma percepcja swojego ciała, poczucie atrakcyjności i jakość relacji partnerskich, a także ogólny stan zdrowia [67]. W badaniach Chwałczyńskiej i wsp. kobiety po mastektomii nisko oceniły swoją atrakcyjność, co skutkowało wyższym poziomem zaburzeń psychoseksualnych [68]. Nieco inne wyniki badań uzyskali Nowicki i Ostrowska. Wysoki poziom akceptacji w ich badaniach osiągnęło ponad $44 \%$. Krychowska-Ćwikła i Jarosz przedstawili badania, w których ponad 80\% kobiet czuło się pełnowartościowymi osobami. Akceptacja oraz właściwa samoocena są ważnym czynnikiem w procesie leczenia choroby nowotworowej [69, 70].

Choroba nowotworowa, uciążliwe leczenie, skutki uboczne i lęk o przyszłość to wydarzenia życiowe, które naruszają dotychczasową równowagę psychofizyczną każdego chorego [71]. Przegląd dotychczasowych badań wskazuje na występowanie zaburzeń psychicznych u ok. 30-50\% chorych onkologicznie [72]. U większości kobiet dotkniętych nowotworem gruczołu piersiowego choroba powoduje pojawienie się negatywnych emocji, takich jak gniew, lęk i depresja $[73,74]$. Do przyczyn powodujących powstawanie zaburzeń depresyjnych w obliczu choroby onkologicznej zalicza się niepewność o przyszłość własną i najbliższych, poczucie zagrożenia i utraty kontroli nad własnym życiem oraz niewystarczającą ilość informacji dotyczących choroby i procesu leczenia [75]. Analiza badań własnych wykazała, że kobiety biorące udział w badaniu mają większą skłonność do tłumienia emocji w zakresie gniewu, lęku i depresji niż osoby z grupy standaryzacyjnej. Również ogólny wskaźnik kontroli emocji osiągnął wartość wyższą u respondentek niż osób z grupy standaryzacyjnej. Grupę standaryzacyjną stanowiły kobiety w okresie menopauzy [54]. Negatywny wpływ na reaktywność seksualną złego nastroju przejawiającego się pod postacią objawów depresyjnych, lękowych czy złości jest powszechnie znany [76]. Speer i wsp. próbowali określić czynniki determinujące dysfunkcje seksualne kobiet chorych onkologicznie. Okazało się, że istotne statystycznie były jedynie czynniki natury psychologicznej, takie jak poziom depresji i dystresu [77]. W prezentowanym badaniu wskaźnik kontroli emocji wzrastał wraz z liczbą dzieci, wiekiem i lepszą sytuacją materialną. Malał natomiast wraz ze wzrostem poziomu wykształcenia. Odmienne wyniki badań uzyskali Nowicki i Rządkowska [78]. Pacjenci mający dzieci małe i samodzielne cechowali się niższym wskaźnikiem kontroli emocji. Wykształcenie determinowało wyższy poziom lęku i depresji. Być może w tym przypadku chodziło o wyższy poziom świadomości związany z konsekwencjami wynikającymi z choroby nowotworowej. Lepsza sytuacja materialna była czynnikiem obniżającym natężenie gniewu, lęku i depresji. Taka sytuacja związana była 
zapewne z lepszą dostępnością do niepublicznego systemu ochrony zdrowia, co w opinii wielu pacjentów gwarantuje wyższe standardy postępowania medycznego, a więc zwiększającego szanse na wyzdrowienie. Pankiewicz i wsp. w swoich badaniach zaobserwowali tendencje do silniejszego reagowania lękiem i przygnębieniem u pacjentek powyżej 50. r.ż., tłumacząc to faktem pogarszania się wraz z wiekiem zdolności przystosowawczych. W wielu doniesieniach stwierdza się jednak, że to pacjentki młodsze, tj. poniżej 50. r.ż., odznaczają się wyższym poziomem emocjonalnego stresu. Stan taki związany może być z destrukcyjnym wpływem na role rodzinne oraz społeczno-zawodowe chorujących kobiet [79].

\section{WNIOSKI}

Przedstawione rozważania teoretyczne oraz przeprowadzone badania empiryczne i dokonane analizy statystyczne dotyczące jakości życia i funkcjonowania psychoseksualnego kobiet po leczeniu operacyjnym raka gruczołu piersiowego prowadzą do następujących wniosków: kobiety, u których wykonano mastektomię z rekonstrukcją gruczołu piersiowego, uzyskały wyższe wyniki niż kobiety po mastektomii bez wykonanej rekonstrukcji w obszarze fizycznego i psychicznego funkcjonowania w zakresie jakości życia. Jakość życia seksualnego wpływa na rokowanie. Uczestniczki badań z wyższym wykształceniem, wysokim statusem materialnym i stabilną sytuacją zawodową odznaczały się wyższym wskaźnikiem nasilenia zachowań zdrowotnych niż kobiety z niskim statusem materialnym i wykształceniem. Respondentki, u których zostało zakończone leczenie onkologiczne, charakteryzowały się niższym nasileniem dysfunkcji seksualnych niż kobiety w trakcie leczenia. Badane kobiety, u których przeprowadzono zabieg oszczędzający lub rekonstrukcję gruczołu piersiowego, charakteryzowały się niższym poziomem FSD niż kobiety bez rekonstrukcji gruczołu piersiowego i z obustronną mastektomią. Badane z wyższym wykształceniem, lepszą sytuacją materialną oraz po zakończeniu leczenia charakteryzowały się wyższym wskaźnikiem kontroli emocji od pozostałych uczestniczek badań. W ciągu 12 miesięcy od zabiegu operacyjnego, pacjentka powinna odbyć konsultację dotyczącą możliwości przeprowadzenia zabiegu rekonstrukcyjnego (odtwórczego) amputowanej piersi.

\section{PIŚMIENNICTWO}

1. Tuchowska P., Worach-Kardas H., Marcinkowski J.T.: Najczęstsze nowotwory złośliwe w Polsce - główne czynniki ryzyka i możliwość optymalizacji działań profilaktycznych. Probl Hig Epidemiol. 2013, 94 (2), 166-171.

2. Wojtyniak B., Goryński P., Moskalewicz B.: Sytuacja zdrowotna ludności polskiej i jej uwarunkowania. Narodowy Instytut Zdrowia Publicznego. Państwowy Zakład Higieny, Warszawa 2012.

3. Didkowska J., Wojciechowska U., Tarkowski W., Zatoński W.: Nowotwory złośliwe w Polsce w 2009. COI, Warszawa 2011.

4. Domagała W.: Choroby sutka. In: Patologia znaczy słowo o chorobie, tom II. Eds.: W. Domagała, J. Stachura. Polska Akademia Umiejętności, Kraków 2009, 1059-1089.
5. Rapport International Agency Research Cancer "GLOBOCAN 2012".

6. Zdrowie i ochrona zdrowia w 2012 r. Główny Urząd Statystyczny, Warszawa 2013,

7. Jassem J., Krzakowski M.: Rak piersi. Zalecenia postępowania diagnostyczno-terapeutycznego w nowotworach złośliwych - 2013 r. Wyd. CMKP, Warszawa 2013.

8. Jassem J., Krzakowski M.: Rak piersi. Praktyczny przewodnik dla lekarzy. Via Medica, Gdańsk 2009.

9. Herman K.: Chirurgiczne leczenie nowotworów w Polsce: dziś i jutro. Onkol Prak Klin. 2011, 7, 6, 311-320.

10. Jeziorski A.: Rak piersi. In: Onkologia. Podręcznik dla studentów i lekarzy. Eds.: J. Kordek, J. Jassem, A. Jeziorski, J. Kornafel, M. Krzakowski, J. Pawlęga. Via Medica, Gdańsk 2007, 202-208.

11. Woźniewski M.: Fizjoterapia w onkologii. PZWL, Warszawa 2012,123-143.

12. Daszykowska J.: Jakość życia w perspektywie pedagogicznej. Wyd. Impuls, Kraków 2007.

13. Dorfmuller M., Dietzfelbinger H.: Psychoonkologia. Diagnostyka. Metody terapeutyczne. Wyd. Elsevier Urban\&Partner, Wrocław 2011.

14. Jaracz K.: Jakość życia wymiar obiektywny i subiektywny. Pielęg Pol. 2002, 1 (13), 28-30.

15. Kowalik S.: Społeczne konteksty jakości życia. Wyd. WSG, Bydgoszcz 2007.

16. Szkup-Jabłońska M., Tutaj E., Jurczak A., Wieder-Huszla S., Brodowska A., Grochans E.: Wpływ warunków socjodemograficznych na jakość życia kobiet w okresie pomenopauzalnym. Perinatol Neonatol Ginekol. 2012, 5 (1), 34-38.

17. Schipper H.: Quality of life studies: Principles of the clinical paradigm, J. Psychosocial Oncol. 1990, 8 (23), 171-185.

18. Schipper H., Clinch J., Powell V.: Quality of life studies: definitions and conceptual isues. In: Quality of life and pharmacoeconomicus in clinical trials. Ed. B. Spilker. Lippincott-Raven, Philadelphia 1996, 11-24.

19. Wołowicka L.: Jakość życia w naukach medycznych. Wyd. UMP, Poznań 2002.

20. Pikor K., Ławiński K., Bar K., Fedus T.: Opieka nad pacjentem w chorobie nowotworowej. Przegl Urol. 2010, 60 (2), 2, 29-34

21. de Walden, Gałuszko K.: Wybrane zagadnienia psychoonkologii i psychotanatologii. Wyd. UG, Gdańsk 1992.

22. Aapro M., Cull A.: Depression in breast cancer patients: the need for treatment. Ann Oncol. 1999, 10 (6), 627-636.

23. Bowers L., Boyle D.A.: Depression in patients with advanced cancer. Clin J Oncol Nurs. 2003, 7 (3), 281-288.

24. Kyranou M., Paul S.M., Dunn L.B., Puntillo K., Aouizerat B.E., Abrams G. et al.: Differences in depression, anxiety, and quality of life between women with and without breast pain prior to breast cancer surgery. Eur J Oncol Nurs. 2013, 17 (2), 190-195.

25. Sucala M., Schnur J., Greene P., David D., Erblich J., Montgomery G.: Cognitive-emotional equation: The relationship between irrational cognitive processes, cognitive contents and specific emotions. Evidence from a sample of breast cancer patients. J Cogn Behav Psychoter. 2013, 13, (2), 503-516.

26. Beisert M.: Seksualność w cyklu życia człowieka. PWN, Warszawa 2006.

27. Jaczewski A., Obuchowska I.: Rozwój erotyczny. Wyd. Akademickie Żak, Warszawa 2002.

28. Lew-Starowicz Z.: Seksualność Polek 1992-2005. Przegl Seksuol. 2005, 4, 19-23.

29. Lew-Starowicz Z., Skrzypulec V.: Podstawy seksuologii. PZWL, Warszawa 2010.

30. Graziottin A., Giraldi A.: Anatomy and physiology of women's sexual function. In: Standard practice in sexual medicine. Eds.: H. Porst, J. Buvat. Blackwell Publishing, Oxford 2006, 289-305.

31. Rawińska M., Czyżkowska A., Lew-Starowicz Z.: Klasyfikacja, etiologia oraz prawidłowe diagnozowanie zaburzeń seksualnych u kobiet - ZSK (FSD Female Sexual Disorders). Czynniki biologiczne, psychoseksualne oraz kontekstualne. Med Ogólna Nauki Zdr. 2012, 18 (4), 334-339.

32. Basson R., Brotto L.A., Laan E., Redmond G., Utian W.: Assessment and management of women's sexual dysfunctions: problematic desire and arousal. J Sex Med. 2005, 2, 291-300.

33. Farrington A.: Zdrowie seksualne kobiet w wieku średnim i powyżejzaburzenia seksualne. Przegl Seksuol. 2006, 8.

34. Basson R., Althof S., Davis S., Fugl-Meyer K., Goldstein I., Leiblum S. et al.: Summary of the recommendations on sexual dysfunctions in women. J Sex Med. 2004, 1 (1), 24-34. 
35. Brotto L.A., Bitzer J., Laan E., Leiblum S., Luria M.: Women's sexual desire and arousal disorders. J Sex Med. 2010, 7 (1 Pt 2), 586-614.

36. Lew-Starowicz Z.: Seksualność kobiet. Raport Vamea. RMC\&KRC, Warszawa 2005.

37. Skrzypulec V., Drosdzol A., Nowosielski K.: Psychoseksualne aspekty życia kobiety. In: Postępy w ginekologii i położnictwie. Ed. M. Spaczyński. PTG, Poznań 2006.

38. Linder B.: Troska o zachowanie prawidłowej seksualności kobiet chorych na nowotwory jako istotny element rehabilitacji psychofizycznej. In: Rehabilitacja chorych na nowotwory z elementami psychoonkologii. Ed. H. Tchórzewska-Korba. Wyd. CMKP, Warszawa 2011.

39. Leiblum S., Rosen R.: Terapia zaburzeń seksualnych. GWP, Gdańsk 2005.

40. Enzlin P., De Clippeleir I.: The emerging field of "oncosexology": recognizing the importance of addressing sexuality in oncology. Belg J Med Oncol. 2011, 5 (2), 44-49.

41. Fobair P.: Concerns about sexuality after breast cancer. Cancer J. 2009 15 (1), 19-26.

42. Fobair P., Stewart S.L., Chang S., D'Onofrio C., Banks P.J., Bloom J.R.: Body image and sexual problems in young women with breast cancer. Psychooncology. 2006, 15 (7), 579-594.

43. Izdebski Z.: Obawy i trudności w życiu seksualnym. Rocznik Lubuski. 2006, 32 (2), 2006, 95-111.

44. Seksualność kobiet w chorobie nowotworowej. Poradnik dla kobiet i ich partnerów. Wyd. Primopro, Warszawa 2012.

45. Makać W., Urbanek-Krzysztofiak D.: Metody opisu statystycznego. Wyd. Uniwersytetu Gdańskiego, Gdańsk 2006.

46. Shapiro S., Lopez A.M., Schwartz G.E., Bootzin R., Figueredo A.J., Braden C.J. et al.: Quality of life and breast cancer: relationship to psychosocial variables. J Clin Psychol. 2001, 57 (4), 501-519.

47. Skrzypulec V., Tobor E., Drosdzol A., Nowosielski K.: Biopsychosocial functioning of women after mastectomy. J Clin Nurs. 2009, 18 (4) 613-619.

48. Żołnierczyk-Zreda D., Wrześniewski K., Bugajska J., Jędryka-Góral A.: Polska wersja kwestionariusza SF-36v2 do badania jakości życia. Wyd.CIOP-PIB, Warszawa 2009.

49. Barnaś E., Skręt A., Skręt-Margieło J., Sobolewski M.: Jakość życia z chorobą nowotworową piersi. Prz Menopauzal. 2009, 1, 15-19.

50. Han J., Grothuesmann D., Neises M., Hille U., Hillemanns P.: Quality of life and satisfaction after breast cancer operation. Arch Gynecol Obstet. 2010, 282 (1), 75-82.

51. Goldberg P., Stolzman M., Goldberg H.M.: Psychological considerations in breast reconstruction. Ann Plast Surg. 1984, 1, 38-43.

52. Mor V., Malin., Allen S.: Age differences in the psychosocial problems encountered by breast cancer patients. J Natl Cancer Inst Monogr. 1994, 16, 394-405.

53. Bulotiene G., Ostapenko V., Veseliunas J.: Influence of social factors on the quality of life after breast cancer surgical treatment. Acta Medica Lituanica. 2005, 12 (2), 79-83.

54. Juczyński Z.: Narzędzia pomiaru w promocji i psychologii zdrowia. Wyd. Pracownia Testów Psychologicznych PTP, Warszawa 2001.

55. Pawletko M.: Styl życia kobiet w trakcie leczenia raka piersi i po jego zakończeniu. In: 0 potrzebie edukacji zdrowotnej kobiet. Ed. J. Bulska. W świetle badań społeczno-pedagogicznych. Wyd. UŚ, Katowice 2013.

56. Wybraniec-Lewicka B., Szpringer M., Czerwiak G., Michalska M., Ciura E.: Styl życia kobiet po mastektomii. Studia Medyczne. 2008, 10, 27-30.

57. Europejski Kodeks walki z rakiem, Wyd. Ministerstwo Zdrowia, Warszawa 2012.

58. Lew-Starowicz Z., Lew-Starowicz M.: Zdrowie seksualne. Psychiatria w Praktyce Ogólnolekarskiej. 2003, 3 (1), 1-5.
59. Hayes R.D., Bennett C., Fairley C.K., Dennerstein L.: What can prevalence studies tell us about female sexual difficulty and dysfunction? J Sex Med. 2006, 3, 589-595.

60. Panjari M., Bell R.J., Davis S.R.: Sexual Function after Breast Cancer. J Sex Med. 2011, 8, 294.

61. Safarinejad M., Shafiei N., Safarinejad S.: Quality of live and sexual functioning in young women with early-stage breast cancer one year after lumpectomy. Psychooncology. 2013, 22 (6), 1242-1248.

62. Laumann E.O., Nicolosi A., Glasser D.B., Paik A., Gingell C., Moreira E. et al.: Sexual problems among women and men aged 40-80 y: prevalence and correlates identified in the Global Study of Sexual Attitudes and Behaviors. Int J Impot Res. 2005, 17 (1), 39-57.

63. Esposito K., Ciotola M., Maiorino M.I., Giugliano F., Autorino R., De Sio M. et al.: Hyperlipidemia and sexual function in premenopausal women. J Sex Med. 2009, 6 (6), 1696-1703.

64. Bakewell R.T., Volker D.L.: Sexual dysfunction related to the treatment of young women with breast cancer. Clin J Oncol Nurs. 2005, 9 (6), 697-702.

65. Den Oudsten B., van Heck G.L., van der Steeg A.F., Roukema J.A., de Vries J.: Clinical factors are not the best predictors of quality of sexual life and sexual functioning in women with early stage breast cancer. Psychooncology. 2010, 19 (6), 646-656

66. White I.: Managing the sexual consequences of cancer and its treatment. Cancer World. 2013, 57, 33-39.

67. Kedde H., van de Wiel H.B., Weijmar Schultz W.C., Wijsen C.: Subjective sexual well-being and sexual behavior in young women with breast cancer. Support Care Cancer. 2013, 21 (7), 1993-2005.

68. Chwałczyńska A., Woźniewski M., Rożek-Mróz K., Malicka I.: Jakość życia kobiet po mastektomii. Wiad Lek. 2004, 57, 5-6.

69. Nowicki A., Ostrowska Ż.: Akceptacja choroby przez chore po operacji raka piersi w trakcie leczenia uzupełniającego. Pol Merkuriusz Lek. 2008, 24 (143), 403-407.

70. Krychowska-Ćwikła A., Jarosz D.A.: Życie po mastektomii. Położ Nauka Prakt. 2009, 8, 4, 24-30.

71. Ganz P., Greendale P., Petersen L., Kahn B., Bower J.E.: Breast cancer in younger women: reproductive and late health effects of treatment. J Clin Oncol. 2003, 21 (22), 4184-4193.

72. Stępień R.: Uwarunkowania społeczno-demograficzne poziomu lęku i depresji u kobiet po radykalnym leczeniu chirurgicznym raka piersi mastektomii. Probl Pielęg. 2007, 15 (1), 20-25.

73. Kosowicz M.: Psychoonkologia - Wybrane aspekty psychologiczne funkcjonowania w chorobie nowotworowej. In: Podstawy onkologii klinicznej. Ed. J. Meder. Wyd. CMKP, Warszawa 2011.

74. Kosowicz M.: Przegląd piśmiennictwa na temat wybranych aspektów funkcjonowania pacjentów onkologicznych w sferze emocjonalnej, poznawczej i behawioralnej. In: Rehabilitacja chorych na nowotwory z elementami psychoonkologii. Ed. H. Tchórzewska-Korba. Wyd. CMKP, Warszawa 2011.

75. Giardini A., Pisoni C., Giorgi I., Borelli V., Scoccia E., Majani G.: ICF, quality of life, and depression in breast cancer: perceived disability in disease-free women 6 months after mastectomy. Support Care Cancer. 2013, 21 (9), 2453-2460.

76. Jakima S., Lew-Starowicz M.: Dysfunkcje seksualne w depresji. Wyd. Most, Warszawa 2010.

77. Speer J.J., Hillenberg B., Sugrue D.P., Blacker C., Kresge C.L., Decler V.B. et al.: Study of sexual functioning determinants in breast cancer survivors. Breast J. 2005, 11 (6), 440-447.

78. Nowicki A., Rzq̨dkowska B.: Depresja i lęk u chorych z nowotworami złośliwymi. Współcz Onkol. 2005, 9 (9), 396-403.

79. Pankiewicz P., Majkowicz M., Krzykowski G.: Anxiety disorders in intimate partners and the quality of their relationship. J Affect Disord. 2012, 140 (2), 176-180 